\title{
Legal Analysis of Application for Determination of Islamic Heirs in Boyolali Religious Court
}

\author{
Surjadi Sjamsir ${ }^{1}$, Faisal Santiago ${ }^{2}$ \\ University of Borobudur ${ }^{1,2}$ \\ \{surjadisjamsir@gmail.com¹, faisalsantiago@borobudur.ac.id²
}

\begin{abstract}
Islamic inheritance law regulates the same thing as the Law of inheritance (western inheritance law and customary inheritance law), namely governing the estate's distribution from a deceased person. This research is normative juridical, namely reviewing the evidentiary process and legal considerations used by judges. The inheritance law used in the Court of Religion is the Islamic Inheritance Law guided by the Compilation of Islamic Law (KHI) in articles 171 to 214 .
\end{abstract}

Keywords: Inheritance Law; Islamic Law; Religious Court

\section{Introduction}

One form of Law applied in Indonesia to regulate the legal relationship between Indonesians is Islamic Law. Islamic Law is a law derived from the Qur'an and Al-Hadith that controls all legal actions for people who adhere to Islam, one of which is about inheritance. Islamic Inheritance Law is the Law that governs everything related to the transfer of rights and or obligations on a person's property after he dies to his heirs. Thus, there are three main elements in the Law of inheritance: heirs, inheritances, and heirs. Inheritance is essentially an integral part of the Law, while the Law is part of Islamic teachings' fundamental aspect.

Islamic Law is a unified legal system. The marriage system determines the family system, and the family system determines the inheritance system. Similarly, in marriage, the form of marriage determines the family's outline or format, and the structure of the family determines the understanding of the family. The knowledge of the family determines the position in the inheritance system. There are three kinds of national inheritance law in Indonesia, namely Islamic inheritance law, western/civil inheritance law, and customary inheritance law. Inheritance law based on Islamic Law applies to those who convert to Islam, civil inheritance law applies to the group of Chinese and European citizens. In contrast, the customary inheritance law is a law that has long been in force among the people, most of which are still unwritten but live in the actions of everyday people, and this customary inheritance law applies to the native Indonesian community.

Islamic inheritance law regulates the same thing as the Law of inheritance (western inheritance law and customary inheritance law), namely governing the estate's distribution from a deceased person. In Islamic Law, inheritance law has a significant position. There is understandable because everyone will experience inheritance problems. Other than that, inheritance issues are straightforward issues to cause disputes or disputes between heirs or 
third parties. Issues related to inheritance and other issues faced by humans have already explained problems in the Qur "an and As-Sunnah with concrete information, so that there is no variety of interpretations, even reaching ijma" (consensus) among scholars and Muslims.

Solving the problem of Islamic inheritance is the authority of the religious judiciary. There was stated in the general explanation of Law No. 7 of 1989 on Religious Justice as amended by Law No. 3 of 2006 on Religious Justice and the Second Amendment to Law No. 50 of 2009 on Religious Justice. In Article 1 Paragraph (1) of Law No. 7 of 1989 concerning Religious Justice, it is explained that the authority of the Religious Court is explicitly limited to people who are Muslims so that the issue of inheritance is the authority of the Religious Court, which in its settlement is based on Islamic inheritance law. As a reference of this Law, it has been stipulated in Presidential Instruction No. 1 of 1991 on the Compilation of Islamic Law.

The renewal of Islamic inheritance law in Indonesia was marked by the birth of the Compilation of Islamic Law through the Instruction of the President of the Republic of Indonesia Number 1 of 1991, dated June 10, 1991, concerning the Compilation of Islamic Law. One of the concepts of renewal of Islamic inheritance law in the Islamic Law Commission (KHI) is granting the right of a deceased heir to his surviving descendants. This rule is listed in Article 185 of the Compilation of Islamic Law, which explains that:

a. The heir who dies earlier than the heir then his position can be replaced by his son, except those who are in Article 173 compilation of Islamic Law

b. The share of the successor heir shall not exceed that of the equivalent heir.

Both verses in the Article have raised the position of a previously deemed person not entitled to an inheritance, to then be placed as a group of heirs who are entitled to receive an inheritance after being appointed to occupy his parents' position who have died first from the heir. But the provision does not specify a particular part that will be obtained for a successor heir nor determine whether all attributes carried by the heir who is replaced are revealed to the heir who returns him, for example, in the case of hijab mahjub. Besides, the Article also does not confirm whether the provision applies only to the heirs of the straight-down line (nubuwwah), or also applies to the heirs of the straight line up (ubuwwah), or also applies to the heirs of the line to the side (ukhuwwah).

The Article gave rise to judges' different interpretations, especially in the Court of Religion, so that the successor heirs' ruling is also allegedly diverse. Even the heirs who have previously obtained a share based on the standard provisions are considered successor heirs based on Article 185 paragraph (1) and paragraph (2) compilation of Islamic Law. The change and renewal of Islamic inheritance law occur markedly in the history of Islamic law thinking. The Judge conducted a legal review by carrying it out through the Court's decision.

\section{Methodology}

This study wants to discuss the process of proof and legal considerations used by judges to decide case No. 0045/Pdt.P/2015/PA Byl. This research is normative juridical, namely reviewing the evidentiary process and legal considerations used by judges to decide case No. 0045/Pdt.P/2015/PA Byl.

A normative legal approach is an approach that is done based on the primary raw material, studying theoretical matters related to legal principles, legal conceptions, legal views and doctrines, regulations, and legal systems using secondary data, including guides, rules, norms, and the power of Law contained in legislation and other practices by studying books, 
legislation and other documents related to research. An empirical legal approach is an approach done in the field by gathering information through observations and interviews with sources related to the problems discussed in this study.

\section{Result and Discussion}

\subsection{Inheritance Designation}

The determination of heirs is not the local RT or RW's authority, but instead the Court of religion's power if the heir and heir are Muslims. In Article 49 letter b of Law No. 3 of 2006 concerning Amendments to Law No. 7 of 1989 on Religious Justice ("Religious Justice Law"), it is stated that: "... The religious Court is in charge and authorized to examine, decide, and resolve the case in the first degree among people who are Muslims in the field of:

A more detailed explanation of what inheritance issues are regulated can be seen in the description of Article 49 letter b of the Religious Justice Law, which reads: "... What is meant by "heir" is the determination of who is the heir, the determination of the inheritance, the determination of the share of each heir, and carrying out the distribution of the inheritance, as well as the determination of the Court on the request of a person about the determination of who is the heir, the determination of the share of each heir..."

The inheritance law used in the Court of Religion is the Islamic Inheritance Law guided by the Compilation of Islamic Law (KHI) in articles 171 to 214 . The heirs can apply for the distribution of inheritance to the Court of Religion either jointly or represented to one of the heirs. Then the Court will determine its respective parts according to Islamic Law. Once the division is done, and the heirs have known their rights, it does not close the possibility of dividing it equally based on willingness. As stipulated in article 183 of the KHI: "The heirs can agree to make peace in the distribution of inheritance after each realizes its share." If the inheritance is controlled by one party and the party does not want to share it, the other heir can sue him to the Court of Religion. It is stipulated in article $188 \mathrm{KHI}$ : "The heirs either jointly or individually can request the other heirs to share the inheritance. If any of the heirs do not approve the request, then the concerned can file a lawsuit through the Religious Court for inheritance sharing."

In-Law No. 7 of 1989 CHAPTER III article 49 reads: "The Court of Religion is in charge and authorized to examine, decide, and resolve cases at the first level between Muslims in the field of marriage, inheritance, wills, and grants conducted based on Islamic Law, waqf and sadaqah. Based on the rejection of Law No. 7 of 1989, the Court of Religion's authority in terms of inheritance is: a. Determine who the heir is. B. Determine which treasures are inherited. c. Determine the share of each heir, and d. He was carrying out the division of inheritance. The Law of inheritance in Islam is derived from Allah SWT's revelation and made clear by His Messenger. This inheritance law was created to be carried out compulsorily by all Muslims. Since the Law was created has never changed because changing the Law of Allah SWT is a sin. Since long ago until now, Muslims have always held fast to the Law of inheritance created by God that is sourced in the holy book of the Qur'an and Hadith of the Prophet SAW. In-Law No. 7 of 1989, the inheritance law was systematically formulated in 5 chapters spread over 37 fasal with the following details: Chapter. It consists of 1 article, general provisions. Chapter II consists of 5 chapters containing the heirs of chapters. III. It consists of 16 chapters, including the magnitude of the heirs of chapters. IV consists of 2 chapters, containing aul and rad. Chapter. V consists of 13 articles comprising the issue of 
wills. Thus at a glance, about Law no. 7 of 1989 , the principle is the same as the Law sourced with the Qur'an and Hadith.

\subsection{Barriers to the Distribution of Islamic Inheritance}

Islamic sharia collapsed not because the enemies of Allah SWT corrupted it, but collapsed by itself due to the stature and ignorance of Muslims themselves to sharia science in their religion. Among the many mistakes in looking at the Law of inheritance in Islamic Law include:

\section{a) Equalizing the Share of Boys and Girls}

Equating the part between boys and girls is a classic problem and most often occurs in a society that claims to be religious and Islamist. Whereas the provision that the position for girls is half of the boy's part is not just a creation or creation of man, but a decree that Directly Allah SWT sent down from the sky to us. It could be because it does not know these rules' existence because so far more educated with the Dutch version of the inheritance system or custom. So all this time never knew about the affairs of inheritance. But the reason can sometimes also not be because of not knowing, but taking this kind of business lightly. It is thought that violating sharia law in this matter is okay because so far, the religion that he practiced is only a matter of rituals and shirks.

When it comes to prayer, fasting, Hajj, celebrating religious holidays, and things that generally smell religious, it may never be separated and always strived. But the turn to divide his heirs is done strangely, not realizing that it is an act against the laws of Allah SWT, and the threat of punishment is not a playful thing. Not a few people go back and forth every year to Hajj as a family, but it is not true how to divide the inheritance because it may be considered an inheritance business has nothing to do with the religion adheres to.

\section{b) Dividing Inheritance While Still Alive}

The case of a living man has been divided into inheritances, we have heard quite often. Sometimes, what concerns him is the property owner's owner, but not infrequently, those who worry about him are the potential heirs. Whereas shariah, there is no distribution of inheritance as long as the property owner is still alive. One of the conditions in the division of the estate is the death of the heir. If the heir is still actual, then there is nothing to do with the division of heirs. All that can be done is a grant or a will, but not an inheritance. Grant: Grant is the grant of property to anyone who wants, without any provider who can and should not receive it. So it could be that the granted is a prospective heir or not an heir. And there is no limit to the maximum amount in the case of property grants. Whatever wealth he wishes to give, the property owner has the right to give to whomever he wishes as long as the property owner is still alive and there is no sign of near death. Wills: As for the will, it is only done when a person has felt close to his death. The one who can be given a choice should not be a tout of heirs, so it can only be those who are not heirs only. And for wills, there is a limit to the maximum amount given, which is only $1 / 3$ of the total amount of property. The remaining $2 / 3$ is the right of the prospective heirs. A common mistake, the property owner, since he was alive, has divided the property to his future heirs by referring to it as the division of inheritance. Even more fatally, the heirs who are forbidden to receive a will are given a choice. 


\section{c) Joint Property of Husband and Wife}

The case of joint property belonging to the husband and wife is inherited from the western legal system (read: Netherlands). But as a result of a long war of thought, even our nation is very attached to this system of property possession, which we know by the term gono-gini property. With the design of shared property or gono-Gini, the implementation of inheritance division becomes ambiguous. For example, once a husband dies, the property cannot be divided into inheritance. And Allah is All-Knowing, All-Knowing. Because the wife was still alive, usually the division of inheritance was delayed because she had to wait for her to die too.

There is a fatal mistake that has been silenced only, even by those who understand Islamic Law. Whereas if we use the system that applies in Islamic sharia, we do not know the term shared property or gono-gini property. And when a couple is married, their wealth does not need to be made one, and suddenly it becomes common property. Such a method is originally a law created by European infidels who carried on to our lives. In the Islamic sharia system, the principle is that all husband's property always remains a husband's property. And that all the property of the wife shall also remain always the property of the wife completely.

But some of the husband's property, there is a right of the wife, but it must be through a clear contract, for example, through the giving of dowry, or a legally mandatory living, or grants, or gifts. Without a definite agreement, the husband's property does not automatically become the wife's property. Indeed, if his wife is only one, he can still be reasoned.

\section{d) His Wife Controls the Property of the Deceased}

One of the bad habits often done by Muslims in this country is that when the husband dies, his wife automatically becomes the sole ruler of her husband's property. Especially if the children are small, arguably, the husband's property must have belonged to the wife entirely. But the wife's right to her husband's property is only $1 / 8$ or $1 / 4$ only. For example, if the husband has children, then the wife is only entitled to $1 / 8$ of her husband's real property. The rest of the 7/8 part becomes the right of his children, who are now orphans. Even if the deceased's children are young, it does not mean that children should not receive the inheritance. They are still entitled to the heritage of his father. But the wife may keep her children's property, for one day it must be handed over to them. If the property should be used for the benefit of children, then the wife must be mandated to spend it and not waste it, let alone control it for the sake of oneself. And if this widow remarried to another man, there is a presumption in society that the man who marries the rich widow becomes the luckiest man. Because it is as if this new husband felt entitled and part of the deceased's estate, but it should not be a piece of the deceased's property that suddenly turned into his right. The property belongs to the deceased's children and his wife only, while the new husband is not the party entitled to the deceased's property.

And if a wife dies, she becomes the sole heir and appoints herself as the only one who is entitled to all her inheritance. So he felt free to remarry and give all his deceased's possessions to his new wife. Whereas it should be, the husband only gets $1 / 4$ of his wife's wealth. The other part that is $3 / 4$ belongs not to him but the other heirs.

e) For Waris, Awaiting One of The Couples to Die 
With the reason to honor the mother who has lived alone because she was left to die by the father who became her husband, the division of inheritance is often not carried out. This is based on a previous mistake, that is, that the property of a husband automatically and indeed becomes the property of his wife as well. This view is not in line with Islamic Law which considers that everyone has a right to their property. And even though a man has a wife, his property does not automatically become his wife's property. And likewise, the property of the wife does not automatically become the property of the husband. So if one of them dies, the property must be divided immediately, without having to wait for his spouse to die first.

The necessity to immediately divide the inheritance is excluded, for example, when there is a technical consideration only, not because it has to wait for death. For example, there are considerations because the property is difficult to sell, so for a while, it is left alone first. Then, of course, it is understandable if a little delayed. But that's what happens in our society; generally, the distribution of inheritance is not immediately implemented. The reason is sole that it still respects their mother. And worse, mothers whose position as the wife of the deceased is no better way of thinking. Usually, because of lack of knowledge and follow-up habits that exist in the community, also feel offended if, while still alive, the husband's legacy has been divided into the deceased's daughter's son.

\section{f) Not the Heir but Feel the most Entitled}

Among the errors in the division of inheritance that often occurs is granting heritage to the deceased to the non-heirs in the estate's name. Among those who are not entitled to inheritance but are often given an inheritance, there are several types:

1. Not Registered In The Heirs' Sturuktur. People who are not included in the heirs' list but often demand to get an inheritance include those whose relationships use the term adopted, stepdaughter and ex.

2. Adopted Family Line. What is meant by a family that uses the term 'adoptive' among others are adopted children, adoptive fathers, adoptive mothers, adoptive siblings, adoptive uncles, adoptive aunts, and so on the appointment of a brother or son is not known in Islamic Law.

3. Step-Status Kelurga Line. In addition to the adopted exit, which does not include the heirs, is the family's path that is a step-step. For example, stepdaughter, stepmother, stepfather, another stepbrother, another father's mother, and so on.

4. Former Family Line. Also, what also does not include the heirs is the family line former status like an ex-husband or ex-wife.

5. It's Not an Heir

6. Those who do not include heirs are the son-in-law, in-laws, and some nephews, brothersin-law, grandchildren of the line of the daughter-in-law, some uncles.

\section{g) For Inheritance Based on Agreement}

A fatal mistake in the distribution of inheritance is the division based on agreement with fellow heirs, regardless of the provisions in the Quran, as-Sunnah, and what has been determined by Islamic sharia. The reason that is usually used is as long as the parties are equally pleased and do not demand anything. So it is considered no longer necessary to be divided based on sharia law. The parable of haraa is that men and women who are not husband and wife agree and are willing to have intercourse outside of marriage, aka adultery. 
Although both like and do not feel harmed, but does not mean that cheating is permissible. Because outside of them, there is Allah SWT who has set the prohibition of adultery.

Similarly, the distribution of inheritance that violates the provisions of Allah SWT. The heirs may willingly share it, but on the other hand, they have agreed to abandon the requirements of Allah SWT. So what should be done previously must be divided under the provisions of Islamic Law. That after that, each party wants to give some of its rations or entirely to its brother. It is up to each of them. And in many cases, the two sides more often submit these affairs to meetings and family agreements. Importantly all are equally sincere and accepting, and the problem is considered resolved. Whether Allah SWT takes it or not, no one cares at all.

\section{h) For Inheritance Using Customary Rules}

One of the fatal forms of error is dividing the inheritance by typical ordinances contrary to the Marwaris Law. The revelation of verses about this inheritance in the Prophet's time saw precisely to replace the procedure of division of estate customarily. Among the customs that are contrary to the mawaris Law in the time of the Prophet (PBUH), among others:

1. Girls don't get an inheritance. When this shari'a about mawaris came down, girls were set to get a share of the estate.

2. Boys who have not been able to bear arms also do not get an inheritance. So the little ones, if their father dies, it is inevitable that they will not get an estate. All that can be inherited is only adult boys, and the size is the ability to fight and bear arms. When Islamic Law comes down, all children, both large and young, will have an inheritance.

3. Adopted children or adopted children receive an inheritance if using jahiliyyah Law before the descent of Islamic Law. With the completion of Islamic Law, the adopted child does not get the heritage, but the Law of raising the child itself is annulled and prohibited.

4. Son Inherits His Stepmother. If a father who has many wives dies, then the first son has the right to inherit his father's ex-wives, aka their stepmothers. With the descent of Islamic Law, stepmothers become forbidden to marry, let alone bequeathed to stepchildren.

\subsection{Obstacles Faced by the Police in Handling Crime Cyber Crime Hate Speech in the Legal Area of the Salatiga Police}

The determination of the heirs of the Court of religion if the heir and heir are Muslims. In Article 49 letter b of Law No. 3 of 2006 concerning Amendments to Law No. 7 of 1989 on Religious Justice ("Religious Justice Law"), it is stated that: "... Religious courts are tasked and authorized to examine, decide, and resolve cases in the first degree between people who are Muslims in the field of inheritance.

A more detailed explanation of what inheritance issues are regulated can be seen in the cause of Article 49 letter b of the Religious Justice Law, which reads: "... What is meant by "heir" is the determination of who is the heir, the determination of the inheritance, the determination of the share of each heir, and carrying out the distribution of the inheritance, as well as the determination of the Court on the request of a person about the determination of who is the heir, the determination of the share of each heir..."

Based on the explanation above, it is clear that the right to issue the determination of heirs is the Court of Religion. This legacy issue can be taken two ways, namely:

a. Through a lawsuit. In the event of a lawsuit filed, there is a dispute over the object of inheritance. There can be because heirs do not want to divide the estate, so that there is a 
conflict between the heirs. The final proceedings of this lawsuit will result in a legal product in the form of a verdict.

b. Through the application submitted by the heirs, if there is no dispute. Against the application, the Court will issue a legal product in the form of.

The process to apply to the Religious Court can be reached by submitting a Letter of Application signed by the applicant or his/her legal representative and addressed to the Chairman of the Religious Court, which includes the applicant's residence. In principle, the Court contains the direction of fast, simple, light costs, as it is reaffirmed in the Supreme Court Circular Letter (SEMA) No. 3 of 1998 on Settlement of Cases, which states: "... Therefore, the Supreme Court considers it necessary to reaffirm and order to you the following matters: That the matters in the Court must be decided and resolved within 6 (six) months including mutation, namely: general civil matters, religious civil and administrative matters of the state, except because the nature and circumstances of the case must be more than 6 (six) months, provided that the Chairman of the First Tier Court concerned must report the reasons to the Chairman of the Court of Appeal...".

Therefore, all cases should be either a petition or a lawsuit examined at the first judicial level, whether a Religious Court or a General Court must be decided or resolved within 6 (six) months.

\section{Conclusion}

The determination of the successor heirs, in its ruling the Judge of the Court of Religion is determined based on the background of the previous legal legislation (Religious Court) and is based on the provisions of article 96, article 180, and article 185 of the Compilation of Islamic Law, as well as QS. An -Nisa verse 11, that the main heir dies is replaced by his wife and children.

The Judge of the Court of Religion's decision in appointing a pure successor heir refers to QS. An-Nisa verse 11, chapters 85, 96, 180, and 185 Compilation of Islamic Law is not the inheritance of madhab Shafi" I by using the origin of the problem in dividing the estate's rights the heirs. Therefore, this decision's quality is under the distribution of inheritance procedure according to Islamic inheritance law (KHI). There is no single thing that needs to be corrected and contrary to the basics of Islamic Law.

\section{References}

[1] Anwar, N. S. (2019). Analisis Transaksi Digital Cryptocurrency Sebagai Investasi Global Dalam Perspektif Hukum Islam (Studi Kasus Dinar Dirham di Makassar).

[2] Gordon, J. M. (1998). Business Law: An Introduction. Business Law: An Introductionby TheBusinessProfessor.Com, 501(c), 428-431.

[3] Santiago, F. (2016). Bunga Rampai Catatan Hukum. Perpustakaan Nasional RI. Katalog Dalam Terbitan.

[4] Supriyanto, Eko Eddya. 2020. Eksistensi Nilai-Nilai Pancasila Dalam Kebijakan Ekonomi Indonesia. 1st ed. Malang: Literasi Nusantara.

[5] Supriyanto, E. E. (2021). Strategi Penerapan Kebijakan Sovereign Wealth Funds (SWFs) di Indonesia: Studi Literatur dan Studi Komparatif Oman. Jurnal Inovasi Ilmu Sosial Dan Politik (JISoP), 3(1), 10-21. https://doi.org/10.33474/jisop.v3i1.6959 
[6] Supriyanto, E. E. (2018). Perang Strategi Pemenangan Pemilu Via Sosial Media (Sebuah Analisis Literatur Dan Sosial Media). In L. K. Alfirdaus \& N. Hasfi (Eds.), Proceeding Seminar Nasional dan Diskusi Ilmiah Media, Pemilu dan Komunikasi Politik Menyambut Tahun Politik Indonesia 2018-2019 (pp. 122-135). Magister Ilmu Politik FISIP Universitas Diponegoro.

[7] Nababan, K. N. N. (2019). Tinjauan Legalitas Transaksi Bitcoin di Indonesia. JuristDiction, 2(5), 1745-1764. 